\title{
Media Daur Ulang (Recycle System) dalam Kemampuan Membaca Bahasa Inggris Awal Anak Usia Dini
}

\author{
Yesi Novitasari ${ }^{\bowtie}$, Danang Prastyo ${ }^{2}$, Selfi Lailiyatul Iftitah ${ }^{2}$, Ardhana Reswari² \\ Mohammad Fauziddin ${ }^{3}$ \\ Pendidikan Guru Pendidikan Anak Usia Dini, Universitas Lancang Kuning, Indonesia(1) \\ Pendidikan Islam Anak Usia Dini, Institut Agama Islam Negeri Madura, Indonesia(2) \\ Pendidikan Guru Pendidikan Anak Usia Dini, Universitas Pahlawan Tuanku Tambusai, \\ Indonesia( ${ }^{(3)}$
}

DOI: $10.31004 /$ obsesi.v6i3.1209

\begin{abstract}
Abstrak
Kemampuan reading bahasa inggris awal anak usia dini membutuhkan kreatifitas orang tua dan pendidik dalam mengembangkan media pembelajaran berbasis daur ulang (recycle system). Penelitian ini merupakan penelitian eksperimen dengan model One-Group PretestPosttest Design. Penelitian ini menggunakan satu kelompok dan melakukan pretest sebelum diberikan perlakuan, dilanjutkan dengan posttest. Adapun teknik sampling menggunakan teknik total sampling yang mencakup seluruh anak kelompok B di PAUD Baitul Amal dengan jumlah 27 anak. Hasil analisis data penelitian menunjukkan adanya tingkat determinasi sebesar $40,6 \%$ yang berarti bahwa terdapat pengaruh signifikan pada media pembelajaran berbasis recycle system terhadap kemampuan reading bahasa inggris awal anak usia dini di Paud Baitul Amal. Dengan demikian pendidik dapat memanfaatkan recycle system untuk memenuhi media pembelajaran reading bahasa inggris awal di pendidikan anak usia dini.
\end{abstract}

Kata Kunci: media recycle system; reading; bahasa inggris awal; anak usia dini

\begin{abstract}
The ability reading early in english for children requires the creativity of parents and educators to develop learning media based on recycle system. This research is experiment research with One-Group Pretest-Posttest Design. This research used a group and gave a pretest before being given treatment, followed by a posttest. The sampling technique uses total sampling technique that includes all group B in Paud Baitul Amal with total of 27 children. The results of data analysis showed a determination level of $40.6 \%$, which means that there is a significant influence on the learning media based on the recycle system on the reading ability in English early at Paud Baitul Amal. Thus educators can take advantage of the recycle system to fulfill early English learning media in early childhood education.
\end{abstract}

Keyword: recycle system media; reading; early english; children

Copyright (c) 2021 Yesi Novitasari, et al.

$\square$ Corresponding author:

Email Address : yesinovitasari@unilak.ac.id (Pekanbaru, Riau, Indonesia)

Received 19 March 2021, Accepted 7 July 2021, Published 11 September 2021 


\section{PENDAHULUAN}

Kemampuan bahasa Inggris dalam era komunikasi merupakan poin penting yang harus dimiliki setiap individu. Bahkan isu globalisasi sekarang menuntut sumber daya manusia yang berkualitas dengan penguasaan bahasa Inggris. Pembelajaran bahasa Inggris awal pada anak usia dini merupakan pemberian pengalaman serta pengetahuan berkaitan dengan penggunaan bahasa inggris melalui rangsangan. Sebagaimana pendapat Tajuddin (2014) bahwa membelajarkan membaca pada anak usia dini harus yang bersifat rangsangan, supaya anak tertarik atau senang dengan kegiatan membaca, misalnya membacakan bukubuku cerita bergambar, bermain tebak gambar yang diselingi dengan pengenalan huruf awal. Namun bahasa inggris yang dimaksudkan tidak kompleks seperti pembelajaran pada orang dewasa. Bahasa inggris masih menjadi bahasa yang asing untuk anak, sehingga dalam proses pembelajarannya harus dilakukan secara bertahap dan berkesinambungan (Novitasari et al., 2019).

Bahasa Inggris awal diberikan kepada anak dengan berbagai macam metode dan media yang menyenangkan dan menarik untuk anak. Adapun komponen yang diajarkan dalam berbahasa inggris awal untuk anak usia dini menurut Scoot (2000) meliputi keterampilan mendengar (listening), berbicara (speaking), membaca (reading), dan menulis (writing). Pada Bahasa inggris awal tidak semua komponen harus dikuasai secara instan, karena semua memerlukan proses yang tidak mudah bagi anak. Namun salah satu komponen yang penting dijarkan kepada anak usia dini yakni membaca (reading), dilanjutkan dengan komponen lainnya. Sebagaimana Suganda (2016) menyebutkan bahwa reading is one of the most important skills in language learning. Dengan kemampuan anak dalam membaca, kemampuan yang lainnya juga akan ikut berkembang seperti menulis, dan lambat laun anak juga akan mampu melafalkan kata yang dibaca, sampai akhirnya anak mampu berbicara dan berkomunikasi menggunakan bahasa inggris secara sederhana. Hal inipun sejalan dengan pendapat Cameron (2001) bahwa the link between reading and oral skills is very strong because children adopt and play with the language of the story.

Kemampuan membaca (reading) dalam bahasa inggris awal mengarah pada perkembangan anak dalam menerjemahkan simbol dan gambar sebagai bentuk proses memaknai suatu tulisan dalam bahasa inggris. Membaca (reading) awal dalam penelitian ini yaitu membaca tulisan pada gambar sebagai suatu upaya pemenuhan vocabulary untuk anak usia dini. Vocabulary ini disesuaikan dengan materi kegiatan yang sedang berlangsung di sekolah. Sebagaimana Yamin (2017) menjelaskan bahwa pada tahap-tahap awal, kegiatan membaca juga sangat bermanfaat untuk mengembangkan kosakata siswa. Untuk itu pendidik juga harus mampu menyesuaikan metode dengan media yang digunakan pada pembelajaran bahasa inggris awal sebagai stimulasi anak usia dini. Karena perkembangan anak tidak terlepas dari pengaruh lingkungan dan stimulasi yang anak dapatkan. Sebagaimana pendapat (Suganda, 2016) teaching children or young learners is not easy because they have their unique characteristics in learning.

Kemampuan membaca awal dapat dilihat dari beberapa kriteria diantaranya (a) Mampu menirukan 4-5 urutan kata; (b) Mampu bercerita dengan gambar yang disediakan guru; (c) Mampu membaca cerita bergambar lalu menceritakan kembali; (d) Mampu menghubungkan gambar dengan tulisan; (e) Mampu membaca beberapa kata berdasarkan gambar, tulisan, dan benda yang dikenal atau dilihatnya; (f) Mampu membedakan kata-kata yang yang mempunyai suku awal yang sama; (g) Anak dapat membaca minimal 4 kata dengan lancar (Sumadoyo, 2013). Dari tujuh kriteria tersebut, peneliti hanya mengambil empat kriteria saja yang paling relevan dengan penelitian ini yaitu reading awal untuk anak usia dini. Adapun keempat kriteria yaitu mampu menirukan 4-5 urutan kata, Mampu membaca beberapa kata berdasarkan gambar, tulisan, dan benda yang dikenal atau dilihatnya, mampu membedakan kata-kata yang yang mempunyai suku awal yang sama, dan dapat membaca minimal 4 kata dengan lancar. Untuk lebih jelas dapat dilihat pada gambar 1. 


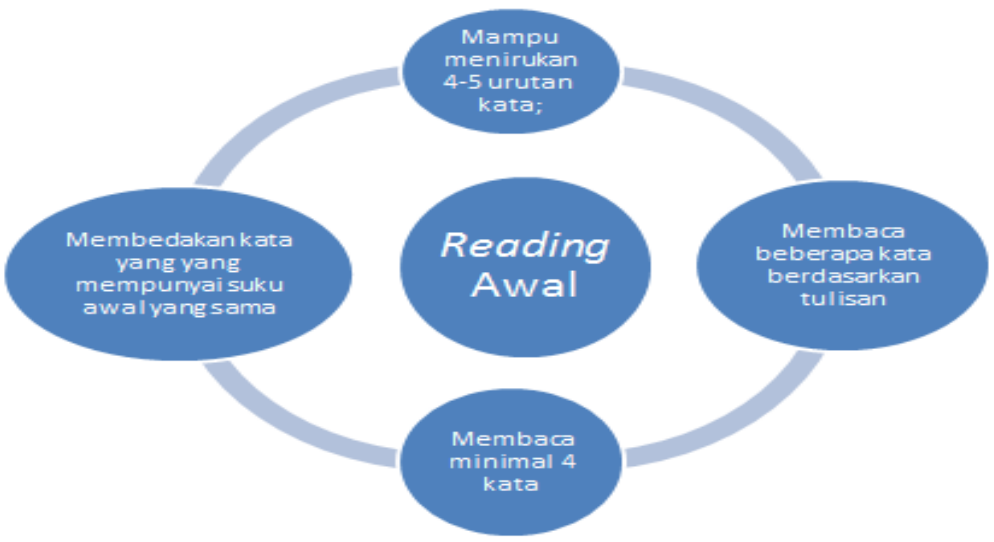

Gambar 1. Empat Kriteria Reading Awal Anak Usia Dini

Media pelajaran dalam pendidikan anak usia dini yaitu segala sesuatu yang dapat digunakan untuk menyalurkan pesan dari pengirim pesan kepada penerima pesan sehingga dapat merangsang pikiran, perasaan, dan minat serta perhatian anak usia dini sedemikian rupa sehingga proses belajar terjadi (Khadijah, 2016). Media yang baik yaitu yang mampu meningkatkan ketertarikan anak dalam belajar, menyenangkan dan dapat menjadi penghantar pesan yang ramah pada anak. Sebagaimana dituliskan Nurrahman (2019) bahwa belajar dengan menggunakan media pembelajaran akan membuat anak aktif tidak hanya duduk namun anak secara mandiri akan memilih sendiri kegiatan belajarnya sesuai dengan keinginannya dengan pengawasan pendidik dan belajar bersama teman sebayanya. Ditambah lagi dengan maraknya pendidikan yang ramah lingkungan. Tentunya media yang dikembangkan juga seyogyanya mencakup keramahan terhadap lingkungan sekitar. Sebagaimana Novitasari et al. (2020) menyebutkan kegiatan pembelajaran bagi anak dilakukan menggunakan media pembelajaran yang menyenangkan dan sebaiknya ramah lingkungan, atau lebih baiknya lagi memiliki nilai ekonomis untuk sekolah sehingga memberikan penghasilan lebih untuk sekolah dan guru. Selanjutnya media yang baik harusnya juga dapat membentuk komunikasi efektif antara pendidik dan anak, serta anak satu dengan anak lainnya. Komunikasi dua arah yang menghasilkan feedback sehingga proses pembelajaran menjadi lebih menyenangkan dengan media tersebut. Khususnya dalam pembelajaran reading bahasa inggris awal anak usia dini, media dapat berupa audio, visual, maupun taktil yang menarik dan sesuai tahapan perkembangannya.

Daur ulang merupakan bagian ketiga dalam proses pengolahan sampah 4R (Reuse, Reduce, Recycle dan Replace). Daur ulang (recycle system) adalah pengolahan kembali bahanbahan bekas dalam bentuk sampah kering yang nilai ekonominya rendah atau bahkan tidak mempunyai nilai ekonomi menjadi suatu barang yang berharga dan berguna bagi kehidupan manusia. Recycle System dapat dilakukan pada sampah-sampah kaca, plastik, kertas, logam, tekstil, maupun barang elektronik. Sebagaimana (Setianingrum, 2018) menjelaskan recycle (mendaur ulang), dilakukan dengan mengubah barang bekas menjadi benda lain yang lebih berguna dan layak pakai. Media pembelajaran bahasa inggris untuk anak usia dini juga dapat dibuat melalui proses recycle system yang memuat tema dan disesuaikan dengan tahapan perkembangan anak, sehingga menjadikannya sebagai media yang ramah untuk anak serta ramah pada lingkungan sekitar. Namun yang terjadi di PAUD media pembelajaran khususnya untuk reading bahasa inggris anak masih sangat terbatas. Hal ini disebabkan karena media yang dijajakan para penjual meningkatkan angka pengeluaran bagi pihak sekolah. Sehingga guru lebih sering menggunakan media gambar sederhana yang kurang menarik atensi anak. Ramainya media pembelajaran yang ditawarkan secara tidak langsung juga dapat menurunkan motivasi guru dalam mengembangkan media pembelajaran bahasa inggris awal anak. Padahal dengan menciptakan media pembelajaran secara mandiri dapat 
menyesuaikan dengan kondisi sekolah, materi kegiatan pembelajaran, karakteristik anak, serta tahapan perkembangannya.

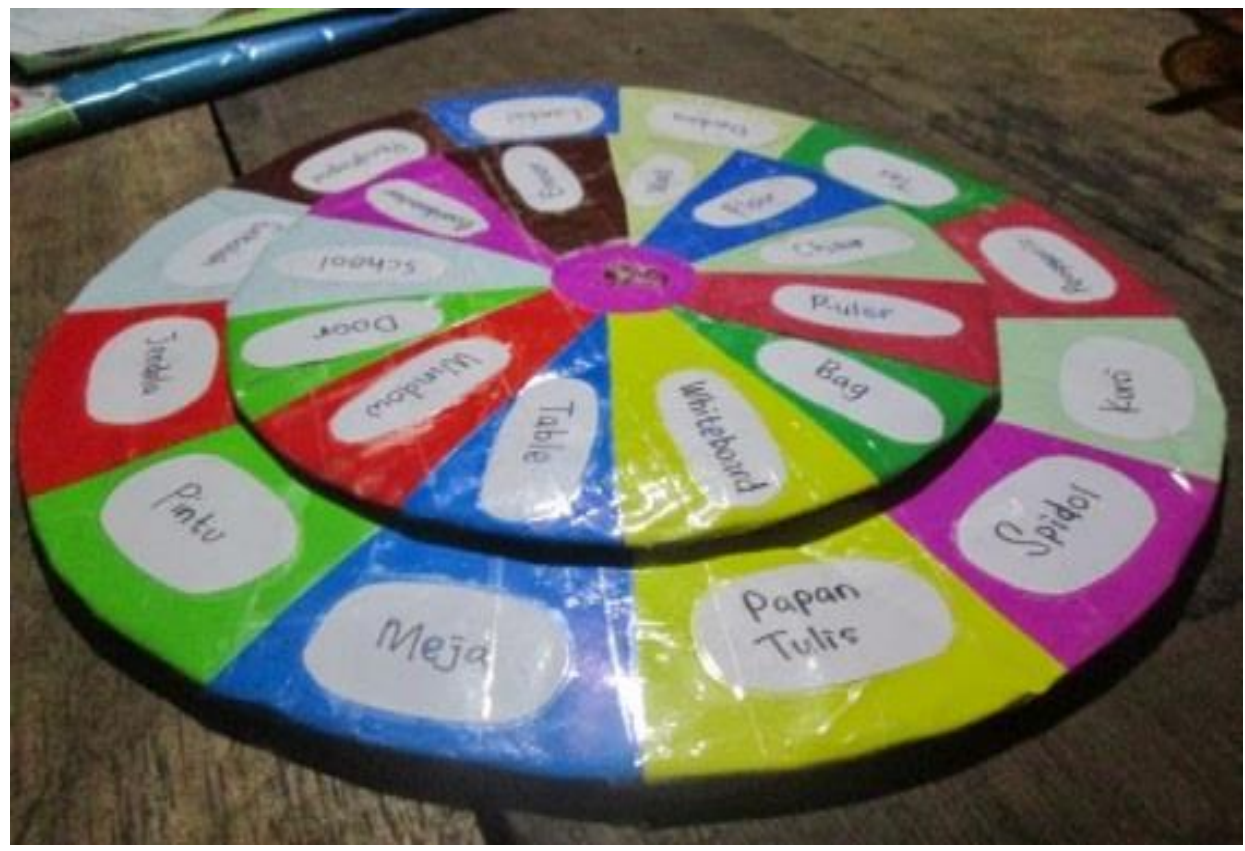

Gambar 2. Media Papan Putar berbasis Recycle System

Lebih jauh, menciptakan media pembelajaran secara mandiri memiliki banyak manfaat yaitu selain dapat menyesuaikan dengan ketersediaan lingkungan, dapat pula mendayagunakan benda-benda yang tidak lagi terpakai menjadi bermanfaat. Sebagaimana media pembelajaran di atas ini yang terbuat dari kardus dan kertas bekas sehingga selain dapat digunakan dalam pembelajaran bahasa inggris untuk anak juga dapat mengolah sampah lebih bijak. Namun demikian kita harus mengetahui apakah media berbasis recycle system berfungsi dan bermanfaat baik bagi perkembangan anak. Sehingga penelitian ini dilakukan agar memperoleh data secara akurat bagaimana kemampuan reading awal anak dengan menggunakan media berbasis recycle system pada pembelajaran bahasa inggris anak usia dini. Media papan putar berbasis Recycle System dapat dilihat pada gambar 2.

\section{METODOLOGI}

Penelitian ini merupakan penelitian eksperimen dengan model One-Group PretestPosttest Design. Penelitian ini menggunakan satu kelompok dengan melakukan pretest sebelum diberikan perlakuan, dan dilanjutkan dengan posttest. Sebagaimana (Sugiyono, 2016) menjelaskan dengan demikian hasil perlakuan dapat diketahui lebih akurat, karena dapat membandingkan dengan keadaan sebelum diberi perlakuan. Gambar 3 adalah rancangan penelitian One-Group Pretest-Posttest Design.

\section{$\mathrm{O}_{1} \times \mathrm{O}_{2}$}

Gambar 3. Rancangan Penelitian One-Group Pretest-Posttest Design

Penjelasan rancangan penelitian ini $\mathrm{O}_{1}$ merupakan nilai pretest (sebelum diberi diklat), $\mathrm{O}_{2}$ adalah nilai posttest (setelah diberi diklat), dan $\mathrm{X}$ merupakan Treatment (perlakuan yang diberikan).

Penelitian ini dilakukan di bulan Januari - Maret 2020 di Paud Baitul Amal. Adapun populasi pada penelitian ini mencakup seluruh anak kelompok B di PAUD Baitul Amal yang 
berjumlah 27 anak. Selanjutnya sampel penelitian diambil dengan menggunakan teknik total sampling yaitu teknik penentuan sampel bila semua anggota populasi digunakan (Sugiyono, 2016). Jumlah populasi dan sampel dapat dilihat pada tabel di bawah ini:

Tabel 1. Populasi dan Sampel

\begin{tabular}{|r|c|c|}
\hline No & Kelompok & Jumlah Anak \\
\hline 1. & B1 & 14 \\
\hline 2. & B2 & 13 \\
\hline 3. & Jumlah & 27 \\
\hline
\end{tabular}

Teknik pengumpulan data dilakukan melalui teknik observasi, dimana observasi dilakukan sebanyak dua kali yakni sebelum dan setelah diberikan perlakuan (treatment). Adapun perlakuan yang diberikan pada anak kelompok B PAUD Baitul Amal yaitu penggunaan media papan putar sebanyak tiga kali pertemuan. Dengan media papan putar hasil recycle system ini anak dapat melakukan berbagai macam kegiatan diantaranya menirukan kata berbahasa inggris, membaca kata berdasarkan tulisan yang tersedia dipapan putar, mencocokkan kata dalam bahasa inggris dengan bahasa indonesia, membedakan kata yang mempunyai sukuawal yang sama. Setelah memberikan perlakuan dan memperoleh data melalui observasi, peneliti melakukan teknik analisis data dengan menggunakan Software SPSS. Berikut hipotesis penelitian dengan $\mathrm{H}_{0}$ jika tidak terdapat pengaruh media pembelajaran berbasis recycle system terhadap kemampuan reading bahasa inggris awal anak usia dini dan $\mathrm{H}_{\mathrm{a}}$ Jika terdapat pengaruh media pembelajaran berbasis recycle system terhadap kemampuan reading bahasa inggris awal anak usia dini.

\section{HASIL DAN PEMBAHASAN}

Pembelajaran bahasa Inggris awal merupakan langkah pertama memperkenalkan bahasa asing kepada anak usia dini. Dengan perkembangan di era milenial bahasa inggris merupakan bahasa yang sangat dominan digunakan oleh masyarakat selain itu diusia 0-8 tahun perkembangan otak manusia sangat melejit diperkirakan mencapai $80 \%$, hal inilah yang menjadi dasar agar anak dapat dibekali sedini mungkin. Data penelitian diperoleh melalui observasi yang dilakukan saat pembelajaran berlangsung baik sebelum diberikan perlakuan dan setelahnya dengan menggunakan Software SPSS. Adapun hasil dapat dilihat di pada gambar 4 .

\section{Paired Samples Correlations}

\begin{tabular}{|ll|r|r|c|}
\hline & & \multicolumn{1}{|c|}{$\mathrm{N}$} & Correlation & \multicolumn{1}{c|}{ Sig. } \\
\hline Pair1 & Pretest \& Posttest & 27 & .638 & .000 \\
\hline
\end{tabular}

\section{Gambar 4. Hasil 1 Pengolahan data SPSS}

Berdasarkan gambar 4 diketahui bahwa nilai signifikan 0,000 lebih kecil dari 0,05 maka $\mathrm{H}_{0}$ ditolak. Dengan demikian $\mathrm{H}_{\mathrm{a}}$ diterima yang artinya terdapat pengaruh media pembelajaran berbasis recycle system terhadap kemampuan reading awal anak usia dini. Dengan mengenalkan bahasa Inggris sedini mungkin, berarti membekali para insan bangsa untuk dapat mengarungi dunia ilmu pengetahuan dan teknologi secara leluasa, namun tetap mengutamakan budaya nasional (Charlotte, 2014). Sebagaimana Tyaningsih (2016) menegaskan bahwa pembelajaran bahasa inggris yang dilakukan sedini mungkin merupakan langkah yang tepat. Namun tanpa media tentu saja akan sulit bagi orang tua dan guru memberikan pembelajaran bahasa inggris kepada anak. Selanjutnya Krisnawan (2015) 
berpendapat bahwa pembelajaran bahasa Inggris akan lebih menyenangkan jika menggunakan media permainan dari pada hanya dengan metode ceramah, karena pada dasarnya anak-anak usia dini lebih menyukai permainan. Sehingga selain metode, media juga harus dipersiapkan oleh orang tua dan guru untuk pembelajaran bahasa inggris anak usia dini.

Selanjutnya Dewi (2017) menjelaskan dalam belajar anak usia dini memerlukan perantara atau yang biasa disebut dengan media pembelajaran, dimana dengan adanya media pembelajaran mampu mengalihkan perhatian anak untuk tidak cepat bosan atau mampu konsentrasi dalam suatu kegiatan dengan waktu yang cukup lama dibandingkan dengan tidak menggunakan media pembelajaran. Adapun media pembelajaran yang dimaksud antara lain media yang penuh warna menarik bagi anak, media yang bisa bergerak merangsang atensi anak, media yang mengeluarkan bunyi yang disukai anak, dan sebagainya. Selain itu secara teknis metode pembelajaran yang baik tentu akan membutuhkan perantara agar efisien dalam penyampaian materi untuk anak usia dini. Sebagaimana Mustika (2015) menjelaskan bahwa kedudukan media dalam komponen pembelajaran sangat penting bahkan sejajar dengan metode pembelajaran, karena metode yang digunakan dalam proses pembelajaran biasanya akan menuntut media apa yang dapat diintegrasikan dan dapat diadaptasikan dengan kondisi yang dihadapi. Bukan tidak mungkin kegiatan pembelajaran berlangsung tanpa media. Namun urgensi media dalam proses belajar anak usia dini sangatlah tinggi dan berkaitan erat pada capaian perkembngan anak. Hal ini mencakup pada kemampuan reading awal anak usia dini. Selanjutnya untuk mengetahui berapa besar pengaruh dilakukan analisis regresi yang dapat dilihat pada gambar 5.

\begin{tabular}{l}
\begin{tabular}{|l|l|c|c|c|}
\hline Mode & $\mathrm{R}$ & R Square & $\begin{array}{c}\text { Adjusted R } \\
\text { Square }\end{array}$ & $\begin{array}{c}\text { Std. Error of } \\
\text { the Estimate }\end{array}$ \\
\hline 1 & $.638^{2}$ & .406 & .383 & 1.76134 \\
\hline
\end{tabular} \\
\hline
\end{tabular}

\section{Gambar 5. Hasil 2 Pengolahan data SPSS}

Berdasarkan gambar 5, R Square bernilai 0,406 atau 40,6\% artinya tingkat determinasi media pembelajaran berbasis recycle system terhadap kemampuan reading awal anak usia dini sebesar 40,6\%. Guru dengan segala tugas pokok dan fungsinya sebagai pengajar dan pendidik sudah seharusnya memiliki kreativitas dalam hal merancang kegiatan pembelajaran baik dari mulainya perencanaan sampai dengan proses penilaian termasuk mengembangkan media. Selain memudahkan dalam proses penyampaian juga membantu anak agar ringan dalam menerima pembelajaran. Sehingga pemilihan media pembelajaran tersebut adalah yang tepat sesuai dengan kebutuhan dan tujuan pembelajaran dan siswa memperoleh hasil belajar yang baik (Nurrita, 2018). Media yang dikembangkan tidak harus mengeluarkan modal yang besar, guru dapat memanfaatkan ketersediaan dari lingkungan sekitar dan diolah kembali menjadi media yang tepat guna. Artinya, media harus disesuaikan dengan tema di Paud, media juga perlu menyeimbangkan dengan tahapan perkembangan anak. Contohnya dalam pembelajaran bahasa inggris dengan tema diriku, maka media yang dibuat mencakup anggota tubuh, alat indera, dan sebagainya yang dibuat dalam bahasa inggris. Sebagaimana disampaikan Rohmalina (2016) bahwa setelah penerapan 3R dalam pengadaan media pembelajaran di PAUD Siaga Kota Cimahi maka hasil yang dicapai adalah pendidik semakin terpacu dan kreatif memanfaatkan barang bekas lainnya sebagai media pembelajaran, sehingga menghasilkan karya. Sehingga dengan adanya recycle system kita tidak hanya menjadi guru yang profesional namun juga menjadi pendidik yang kreatif serta inovatif, bahkan menunjukkan bukti cinta terhadap lingkungan. Sebagaimana direkomendasikan Tyaningsih (2016) bahwa dengan pemahaman dan pendalaman yang baik diharapkan guru 
dapat menggunakan kreativitasnya dalam mengajar sehingga proses pembelajaran menjadi lebih efektif dan tepat.

Media yang digunakan saat pembelajaran bahasa inggris membuat anak tertarik dan bersemangat, meskipun media yang digunakan terbuat dari bahan-bahan tidak terpakai yang diolah kembali. Sebagaimana hasil penelitian diketahui bahwa terdapat pengaruh media pembelajaran berbasis recycle system terhadap kemampuan reading awal anak usia dini di Paud Baitul Amal. Hal ini tampak jelas pada proses pembelajaran, anak tampak antusias menggunakan media dan mencobanya sesuai arahan yang diberikan oleh guru. Kegiatan pembelajaran berlangsung sambil bermain dan tidak menyulitkan ataupun memberatkan anak. Hal ini sejalan dengan hasil penelitian Novitasari et al. (2020) bahwa meskipun media terbuat dari bahan bekas dengan sistem recycle system, media dapat dimanfaatkan di PAUD untuk menyampaikan materi pembelajaran. Media berbasis recycle system yang digunakan sangat bermanfaat dalam proses dan hasil pembelajaran anak. Berdasarkan hasil penelitian media recycle system berpengaruh signifikan terhadap kemampuan reading bahasa inggris awal anak usia dini dengan tingkat determinasi $40,6 \%$. Hal ini sejalan dengan hasil penelitian Handayani et al. (2013) bahwa penggunaan media bahan bekas terbukti dapat meningkatkan keterampilan meronce pada siswa kelas V SDN Ori.

\section{SIMPULAN}

Berdasarkan hasil penelitian, maka dapat disimpulkan bahwa media pembelajaran bahasa inggris berbasis recycle system berpengaruh signifikan terhadap kemampuan reading bahasa inggris awal anak usia dini dengan nilai signifikan 0,000 lebih kecil dari 0,05 dan besaran nilai determinasi mencapai 40,6\%. Dengan demikian guru bisa memanfaatkan recycle system untuk memenuhi media pembelajaran reading bahasa inggris awal pada pendidikan anak usia dini.

\section{UCAPAN TERIMAKASIH}

Peneliti mengucapkan terima kasih kepada seluruh pihak yang telah berkontribusi dan berpartisipasi dalam penelitian ini, sampai dengan selesainya penelitian dan publishnya artikel ini. Semoga tulisan ini dapat bermanfaat bagi mahasiswa, guru, peneliti selanjutnya, dan seluruh pembaca.

\section{DAFTAR PUSTAKA}

Cameron, L. (2001). Teaching Languages to Young Learners. Cambridge University Press. https://doi.org/10.1017/CBO9780511733109

Charlotte, A. (2014). Pembelajaran Bahasa Inggris bagi Anak Usia Dini Versus Budaya Lokal. Jurnal Cakrawala Dini, 5(2), 63-72.

Dewi, K. (2017). Pentingnya media Pembelajaran untuk Anak Usia Dini. Raudhatul Atfal: Jurnal Pendidikan Islam Anak Usia Dini, 1(1), 81-96. https://doi.org/10.19109/ra.v1i1.1489

Handayani, P., Suryandari, K. C., \& Budi, H. S. (2013). Penggunaan Media Bahan Bekas untuk Meningkatkan Keterampilan Meronce pada Siswa Kelas V SDN Ori Tahun Ajaran 2013/2014. Jurnal FKIP UNS, 2(1), 1-5.

Khadijah. (2016). Pengembangan Kognitif Anak Usia Dini. Perdana Publishing. https://www.google.com/url?sa=t\&source=web\&rct=j\&url=https://core.ac.uk/do wnload/pdf/53037014.pdf\&ved=2ahUKEwjO79u9vHrAhVLfSsKHYWkCSgQFjAAegQIAxAB\&usg=AOvVaw0_S_abnQpYEkF4FJ8At $\underline{\text { OXT }}$

Krisnawan, G. N. A. (2015). Rancang Bangun Aplikasi Game Edukasi Bahasa Inggris Untuk Anak Berbasis Android. Prosiding Konferensi Nasional Sistem Dan Informatika (KNS\&I), 86, 955-960. 
Mustika, Z. (2015). Urgenitas Media Dalam Mendukung Proses Pembelajaran Yang Kondusif. CIRCUIT: Jurnal Ilmiah Pendidikan Teknik Elektro, 1(1), 60-73. https:// doi.org/10.22373/crc.v1i1.311

Novitasari, Y., Bastian, A., \& Putri, A. A. (2019). Analisis Pengembangan Bahasa Inggris Awal Anak Usia 5-6 Tahun. PAUD Lectura: Jurnal Pendidikan Anak Usia Dini, 2(02), 111118. https://doi.org/10.31849/paud-lectura.v2i02.2513

Novitasari, Y., Filtri, H., \& Herdi. (2020). Media Pembelajaran Bernilai Ekonomis Berbasis Recycle System untuk Pendidikan Anak Usia Dini. Jurnal Obsesi: Jurnal Pendidikan Anak Usia Dini, 4(2), 1-7. https:// doi.org/10.31004/obsesi.v4i2.296

Nurrahman, A. (2019). Peran Serta Media Pembelajaran dalam Memfasilitasi Belajar Anak Usia Dini. Jurnal Pendidikan Anak, 7(2), 101-105. https:// doi.org/10.21831/jpa.v7i2.24453

Nurrita, T. (2018). Pengembangan Media Pembelajaran untuk Meningkatkan Hasil Belajar Siswa. Jurnal Misykat, 3(1), 171-187. https:// doi.org/10.33511/misykat.v3n1.171

Rohmalina. (2016). "3R" (Reduce, Reuse, Recycle) sebagai Inovasi Media Pembelajaran Paud dalam Menyongsong Indonesia Bebas Sampah di Paud Siaga Kota Cimahi. Tunas Siliwangi: Jurnal PGPAUD, 2(2), 43-53.

Scoot, W. A. (2000). Teaching English to Children. Longman Inc.

Setianingrum, R. . (2018). Pengelolaan Sampah Dengan Pola 3 R Untuk Memperoleh Manfaat Ekonomi Bagi Masyarakat. Jurnal Berdikari, 6(2), 173-183. https:// doi.org/10.18196/bdr.6144

Suganda, L. A. (2016). Teaching Reading For Young Learners In Efl Context. Journal Of English Literacy Education, 3(1), 80-88.

Sugiyono. (2016). Metode Penelitian Bisnis Pendekatan Kuantitatif, Kualitatif dan R\&D. Alfabeta.

Sumadoyo, S. (2013). Penelitian Tindakan Kelas. Graha Media.

Tajuddin, Y. (2014). Belajar membaca bagi anak usia Dini: stimulasi menumbuhkan Minat baca anak. Jurnal ThufuLa, 2(1), 127-147. https:// doi.org/10.21043/thufula.v2i1.4269

Tyaningsih, A. . (2016). Pembelajaran Bahasa Inggris Pada Anak Usia Dini Berbasis Proses Pemerolehan Bahasa Pertama. Jurnal Barista, 3(1), 74-82.

Yamin, M. (2017). Metode Pembelajaran Bahasa Inggris Di Tingkat Dasar. Jurnal Pesona Dasar, $1(5), 82-97$. 